\title{
Social Performance and Family Firms Succession
}

\author{
Bughin Christiane, Colot Olivier, Comblé Karin, \\ Croquet Mélanie, Dupont Claire, Finet Alain \\ UMONS, Mons, Belgium
}

\begin{abstract}
Succession accounts for a crucial moment in a family business because it can impact the durability of its activities. The aim of this paper is to analyze the influence of succession on family firm social performance. Using paired samples methodology, three hypotheses were tested upon a sample of Belgian family SMEs that had been handed on. This methodology compares the performances of family SMEs handed on to an internal successor with those handed on to an external successor. Seventy eight pairs of "transmitted SMEs/not transmitted SMEs" were constituted and analysed. Results of this research show that it is desirable to give priority to an internal successor in order to carry out the adequate strategic choices and to obtain the trust of the company staff. The overall results show that social performance of SMEs was affected by the succession (increase in worker productivity, wage cuts, and payroll contraction). However, only the hypothesis of a decrease in workers' wages could be confirmed in the case of the internal successor. This result confirms the conclusions of previous studies highlighting differences of opinion as to the link between the performance of handed-on companies and the nature of the successor.
\end{abstract}

Keywords: family firm, CEO turnover, human resource management, performance, successor

\section{Introduction}

Family businesses are the most widespread type of company in the private sector, so they play a considerable role in the economy of most countries and represent between $50 \%$ and $90 \%$ of the gross domestic product of all market economies (Kenyon-Rouviniez \& Ward, 2004). But according to Carlock and Ward (2001), a significant number of family companies do not survive by the change of generation. The succession of companies thus represents an important issue (Cadieux, 2006; Bégin, 2006; Senbel \& St-Cyr, 2006). Training programs related to this question have become numerous, in line with political programs of economic development that inevitably comprise a component of awareness of these problems. More precisely, the question of internal or external successor is important because it induces different strategic methods, but especially because it could impact the success of the succession of the family company.

At the empirical level, a certain number of studies have been conducted assessing the financial performance of family companies according to whether they are transmitted to an internal or external person.

Bughin Christiane, Professor of Accounting, Accounts Department and Management, UMONS.

Colot Olivier, Professor of Accounting and Entrepreneurship, Accounts Department and Management, UMONS.

Comblé Karin, Professor of Accounting and Audit, Accounts Department and Management, UMONS.

Croquet Mélanie, Professor of Finance, Department of Finance, UMONS.

Dupont Claire, Scientific research worker, Department of Analysis of Labour Economics, UMONS.

Finet Alain, Professor of Management, Department of Financial Management and Corporate Governance, UMONS.

Correspondence concerning this article should be addressed to Colot Olivier, 17 Place Warocqué, 7000 Mons, Belgium. E-mail:

Olivier.Colot@umons.ac.be. 
However, the results of those works are difficult to generalize and are based on an exclusively financial conception of performance. In addition, most of the works undertaken on the topic of performance following the succession focused on large listed family companies. In spite of the importance of the context of the succession of family companies, the empirical literature is lacking of two reasons.

First, since small and medium-sized businesses are often family-based and generally not quoted, they are less subject to studies than the quoted firms. Second, very little research has investigated the impact of family firm's succession on social performance, which nonetheless determines their success ${ }^{1}$. Indeed, "if succession of a company is the transfer of an inheritance, it is also and above all the transfer of a set of employees with a collective know-how" (Saoudi, 2007).

This research aims to assess the social performance of family businesses that are not listed at the conclusion of their succession, depending on whether the new head is internal or external. First, this paper focuses on the empirical work that has been undertaken in this field and considers the limits of these previous studies, in particular the way they assess performance. Second, this paper focuses on the succession of family companies by considering the social dimension of performance.

Analysis of the literature leads to think that internal succession is preferable. The goal of this research is to confirm or contradict this idea thanks to a study of the social performance of unlisted Belgian family businesses at the conclusion of their succession, according to whether the new person is internal or not.

\section{The Performance of Family Companies According to the Type of Succession}

Studies focusing on links between financial performance of transmitted family companies and the type of succession (internal or external) lead to contradictory results. For some researchers the choice of an internal person is preferable. Anderson and Reeb (2003) showed that large family companies directed by people from the same family record performances that were completely comparable to those of companies directed by the founder. Along the same lines, Lin and Li (2004) showed that performance tended to be better in companies where the succession was internal than in those where it was external. According to these authors, transfer to an external involves more organisational changes in the short run, which can be prejudicial for the performance of the family company, especially if, prior to its succession, it was planned in logic of value creation.

For other studies contradictory results are obtained. For instance, Huson, Malatesta, and Parrino (2004) were interested in the financial performance and the change of 1,344 leaders between 1971 and 1995. Starting from financial indicators, they showed that performance worsened before the change and improved thereafter. This increase in performance is more significant when an external manager is involved. Morck, Strangeland, and Yeung (1998) also highlighted that family companies directed by the heirs presented weaker operational performance.

These authors conclude that obtaining control by heritage could alter the growth of the company. Also, in a study related to the operational performance of listed French family companies between 1994 and 2000, Sraer and Thesmar (2004) showed that family companies directed by heirs were no more profitable than those transmitted to external managers. In the same way, according to a study of more than 700 listed French companies (Sraer \& Thesmar, 2007), the profitability of family companies does not seem to be affected by the

\footnotetext{
${ }^{1}$ Let's note that a high level of failure is observed within the two years following the succession. This result could be explained by a bad application of the preparatory process of the operation, but also with organisational and human problems (Deschamps, 1998).
} 
person who manages the business.

Perez-Gonzalez (2002) analyzed the performance of the succession of quoted family companies considering whether it was internal or not (335 successions of American companies included in the Compustat database). The companies for which the successor belongs to the founder's family or to that of a major shareholder undergo a degradation of their return on assets, which is not the case for companies with an external successor: family companies consider the family ties rather than merit to choose the successor. With the same idea, Morck and Yeung (2003) showed that company spirit was not necessarily transmitted from generation to generation. The heirs could avoid adopting a process of innovation.

From these empirical studies, on the one hand, it is not possible to unanimously support one type of succession or the other. These studies are generally based on a limited vision of performance, focused entirely on financial aspects. On the other hand, the majority of those researches focused on large quoted companies.

So, small or medium-sized businesses that are family-run and generally unlisted are the subject of the present study. Because family SMEs are usually characterized by a very specific social scheme, this study will consider a social approach to performance which seems more appropriate to the context of such SMEs. An adapted theoretical framework of analysis is proposed so as to formulate some assumptions.

\section{Internal or External Succession? An Answer Through Social Performance}

A crucial step during the process of succession is choosing the successor and future leader, who will generally also be the new owner. This choice can be an external or an internal person (a company employee, or more frequently, a family member of the leader-owner).

\section{The Natural Preference for an Internal Process}

The family usually prefers to transmit their business to a family member, then to an employee and as a last resort to a third party (Culliere, 2008). According to a study by Miller and Le Breton (2005), the success of family companies would be conditioned by the combination of the four Cs (continuity, community, connection, and command).

More precisely, the principle of continuity occupies an important place in the family company and is necessary for achieving the fundamental mission. To ensure this continuity, successful family companies patiently invest in the development of a core of skills.

In this context, one generation manages the family company until a younger family member is ready to take it again. Chua, Sharma, and Chrisman (1998) proposed a set of means to develop the skills of the successors. This typology takes into account education, experience in the family company (student jobs, internships, etc.), experience outside of the family company and previous performances (so as to prove the successor's competence, which will contribute to his legitimacy inside the firm). However, the career offered to the family successor does not necessarily correspond to his aspirations, or other opportunities could be more interesting. Stavrou (1999) questioned 153 American students and noted that more than $20 \%$ of these respondents do not intend to work in the family business.

In addition, the family successor may be lacking experience and skills. Thus, in some cases, the company will choose an external person, for various reasons such as lack of qualifications or bad relations in the family.

\section{The Social and Emotional Specificity of Family Companies}

Family companies are characterized by a strong social and emotional context because of a single 
atmosphere creating a powerful feeling of belonging. Thus, the typology of the four Cs of Miller and Le Breton (2005) also referred to the principle of community, a factor that was associated with the loyalty of the personnel working in these companies ${ }^{2}$. Thus, family companies have to be considered as tribal communities in which not only the family but also the rest of the staff try to achieve their mission. This attitude is anchored in strong values that are systematically transmitted to everyone. In return, the family company is loyal to its employees, who are well paid and given interesting jobs with career prospects. In other words, the family diffuses codes of conduct to maintain cohesion inside the business: "The family impregnates its members with collective knowledge that represents the entire set of statutory values and standards of behavior embodied by the family group” (Arregle, Durand, \& Very, 2004).

In addition, family companies are characterized by a specific capital (theory based on the RBV—Resource-Based View_approach). For Baron and Markman (2000), this capital corresponds to the resources that individuals acquire through knowing other individuals, either by belonging to their social network or by being recognized and appreciated by them.

According to Arregle et al. (2004), familiarism results from the positive overlap of two specific capitals: on the one hand, interactions between the family members, and on the other hand, relations resulting from exchanges with customers, suppliers but also workers.

Consequently, in case of succession, the workers, who are brought together within a social network around common family values, are likely to fear possible changes in the culture that might be induced by the arrival of a new leader.

Special attention must then be paid to the social harmony of family companies that are to be transmitted, especially when they are small and not necessarily prepared for this step.

Succession has consequences as in the family system that is in search of new objectives as well as in the company system for employees who consider succession as a (kind of) breach of the psychological contract that linked them with the company. (Meier, 2002, p. 116)

For transmitted family companies, the human dimension and the resulting social performance are central questions to the extent that the context of the succession is strongly determined by human interactions (Culliere, 2008). In a more general way, the failure of succession is $80 \%$ due to the human factor (Chabert, 2005; Deschamps \& Cadieux, 2008).

\section{Succession and Social Performance}

As developed above, if the succession proves to be essential for the survival of a family company, it cannot really be implemented without taking into account the human aspects. The reactions of the staff, in particular of the initial leader and the values he favoured, can possibly be problematic for the company. Thus, staff adhesion and involvement constitute a problem that can frequently occur during succession. According to the investigations of the Bank of Development of SMEs in France (BDPME, 1998) and OSEO BDPME (2004), the lack of competence or low productivity of human resources (46\%) have been pointed out. In Belgium, this succession problem is in the second position with $13.7 \%$ (Colot, 2010). Variables such as staff productivity, the manpower or the pay scale ${ }^{3}$ constitute indicators of social performance that must be analyzed following the

\footnotetext{
${ }^{2}$ According to Allouche and Amman (2000), family SMEs would be made up of older people than in non-family SMEs and would employ engineers and executives who have been in the company for a long time.

${ }^{3}$ It is known that the distribution of benefits can reinforce the sense of belonging in a company and create a stimulating climate (Sekiou, Blondin, Fabi, Besseyre des Horts, \& Chevalier, 1993).
} 
company succession.

In addition, staff reactions can vary according to the kind of succession (internal or external). Whereas the insiders are rather well accepted, the arrival of an external person implies more resistance. Succession to insiders induces confidence in the future (Deschamps, 2002). Moreover, according to Caby (1994), the arrival of an external leader is a traumatizing event for the company: The new manager needs time to develop necessary managerial skills and to improve his knowledge of the company. In human resource management literature, this is called "organisational socialization" which corresponds to a process of training in the attitudes, behaviours, and knowledge that the new leaders must acquire to fulfil their functions (Boussaguet, 2008). This process is very important for the external manager who does not create the firm (Deschamps \& Cadieux, 2008; Saoudi, 2008). So even if the external successor is the right person to manage the company, this training represents a problem that does not occur when the succession follows an internal process. In effect, "the new leader can suffer from difficulties of adaptation and integration, in particular if it is a manager coming from outside” (Boussaguet, 2006). The probability of failure is consequently greater with an external succession because not knowing the company from inside adds to the "traditional" risks of succession (Picard \& Thevenard-Puthold, 2004). In the same way, succession to a family member who has a good knowledge of the company (its values, its operating process, etc.) can facilitate the process of succession. In his study, Mouline (2000, p. 209) concluded that it is in the family that the aspirations, know-how, standards, and values have to be developed and thus it was easier for internal successors to manage the company. Along the same lines, Kotter (1982) and Parrino (1997) stated that internal successors had two main advantages. They have a better knowledge of the company (products, markets, competitors and customers, personnel, technology, structure, etc.). In addition, they already have social networks from which they can acquire specific information. For Picard and Thevenard-Puthold (2004), succession to an external person is riskier because an internal person knows the structure and the business environment. It is known that a new internal manager is more easily accepted. "The proximity of the preliminary bond with the company is thus a decisive element of legitimacy for the new manager" (Culliere, 2008). The common consequences observed for employees during a succession (lower employee commitment to the company, conflicts of power, behaviors that are harmful to work, strained relations with the successor-Deschamps, 1998) thus are probably attenuated in the case of internal succession. According to a study of 3,000 successions between 1997 and 2004, "the successor's knowledge of the company is crucial for success: the risk is very low for family successions and the company has twice more chances of success with an internal business transfer than an external one” (Chabaud, Estay, \& Louart, 2008).

Allouche and Amann (1998) and Bégin (2006) also noted that one of the advantages of the succession of family companies to a family member was in particular the strong commitment of the employees, because of the strong culture of family companies, which was a consequence of beliefs, values, family history as well as social relations (Flament, 2006). Ainsworth and Cox (2003) noted that this culture presented certain stability when the family company was transmitted to future generations. Thus, the shock frequently observed in contact with the successor culture of the bought company (Deschamps, 1998) is probably reduced when the succession is internal. On the other hand, in the event of an external succession, employees must to some extent go from a situation of attachment to a situation of uncertainty (Saoudi, 2007). More precisely, Sraer and Thesmar (2007) noted that human resource management was more protective when the family company was directed by an internal manager than by an external one named by the family. In effect, the new management coming from within the business family would have a longer term vision of the company than an external manager, for 
whom one way to improve company performance in the short term is to lay off part of the staff. According to Saoudi (2008), any external transfer involves a strategy of change-in particular at the human resource management level-in order to get more freedom.

However, employees of family companies that are headed by heirs must accept weaker wages without consideration of their productivity (Sraer \& Thesmar, 2007). This wage discount is estimated between $5 \%$ to $10 \%$ (which would often lead family companies directed by heirs to release a higher trading margin than family businesses directed by an external manager).

Lastly, in spite of the natural predispositions for an internal successor to be honest with the staff, Barach, Ganitsky, Carson, and Doochin (1988) concluded that according to a survey carried out on 30 children occupying a management position within the family company, a period from two to four years is often needed for the child to be accepted by the staff.

Hypothesis: There is a positive relation between the choice of an internal successor and the social performance of a family company after its succession.

\section{Methodology}

This empirical study focuses on Belgian family SMEs. The financial data to carry it out were collected from the Belfirst database. As for information making it possible to identify the Belgian family companies, the absence of a useful database justified the use of a questionnaire-based investigative technique so as to collect the necessary information.

\section{Population}

The investigation was thus carried out for all Belgian SMEs that were created before December 31, 1990. This choice was made for two reasons: on the one hand, so that the family character or lack thereof is quite impregnated in the company, and on the other hand, so as to collect a maximum number of SMEs that had already been subject to a succession. Within this group of Belgian SMEs, a simple random sampling without handing-over was carried out of 2,000 companies.

\section{Sample}

The investigation finally gave rise to 391 useable answers, an answer rate of $23.86 \%$. The statistical representativeness of this sample was tested on the basis of three criteria: geographical location, the branch of industry, and manpower (number of workers). With the probability threshold of $5 \%$, the null assumption of identical distributions cannot be rejected for each variable taken into account.

To determine if the SMEs in the sample are family-based or not, it was considered that the SME is a family business when it satisfies at least two of the following three criteria (Colot, 2010):

- A family holds at least $50 \%$ of the shares in the company;

- A family has a decisive influence on the company strategy and on the succession decisions of the company;

- The majority of the board of trustees are family members.

Two reasons justify the choice of this definition for family SMEs. On the one hand, this definition has the advantage of being based on clear and measurable criteria, in opposition to more subjective and arbitrary qualitative definitions. In addition, this definition is very close to the most recent description of the family company.

Among the 391 companies in the sample, 318 can be considered as family businesses. With a rate of 81.33\% of family SMEs (statistically significant with a threshold of $1 \%$ ), this research obtains similar results to 
previous studies undertaken on the importance of family SMEs in Belgium (Wtterwulghe, Janssen, Mertens, \& Olivier, 1994: 82\%; Jorissen, Laveren, Martens, \& Reheul, 2002: 82.8\%). Moreover, the investigation made it possible to identify 159 successions of SMEs, including 130 in family businesses.

\section{Statistical Matching}

The matched samples technique was used to analyze the social performance of family SMEs after succession based on the total sample, and, in a further step, according to their recovery by an internal or external change. SMEs are thus compared with other SMEs that are as similar as possible, except they are not the subject of a succession. This technique makes it possible to eliminate the demographic data (size, branch of industry). To proceed to pairing, it was necessary to choose "criteria considered to be relevant, so as to make sure that the measured effect comes from variables studied and not of the difference in composition of samples" (Thietart, 1999, p. 198). Looking back at other empirical studies using this method (Caby, 1994), economic activity and size (estimated by manpower and/or the total credit) were mainly used. It is indeed known that certain countable indicators are sensitive to sector and size (Ooghe \& Van Wymeersch, 1990, p. 395).

With regard to the choice of the size criterion, total assets are favored (it is about one of the three references in keeping with companies according to the Belgian accounting law, along with turnover and manpower). The counter sample is thus given as follows:

- The branch of industry: NACEBEL code with 4 digits ${ }^{4}$;

- The total assets cannot vary by more than $20 \%{ }^{5}$.

At the beginning of the sampling of 130 family successions, the pairing carried out according to these criteria led to 78 pairs "transmitted SMEs/not transmitted SMEs" (not transmitted SMEs were identified based on the data resulting from the investigation insofar as the annual accounts did not give any information related to successions). Lastly, two groups of transmitted family SMEs were distinguished: those with internal change and those with external change.

\section{Comparison Test}

The sample of transmitted SMEs was compared to the counter sample (not transmitted SMEs) by means of a statistical test that makes it possible to compare observations. Thus, for each variable, the differences between the paired data are calculated while systematically withdrawing the corresponding value for the control SME from the value for the transmitted SME. The comparison test is then based on the average of the differences between the paired values. According to a student test, it is possible to accept or reject the null hypothesis (see Cooper \& Schindler, 2006, p. 505) ${ }^{6}$.

\section{Selected Indicators of Countable Social Performance}

Since Belgian SMEs are not subject to the obligation to deposit a local balance sheet, the social

\footnotetext{
${ }^{4}$ It was sometimes necessary to soften these selection criteria. The 3-digit NACEBEL code was used for 23 companies, and the 2-digit code for 34 businesses.

${ }^{5}$ When several "not transmitted" companies corresponded to the profile, the one that presented the total assets nearest to those of the transmitted companies was chosen.

6 This method does not assume normality of distribution (Afnor, 1988, p. 366; Heldenbergh, 1999, p. 205), which is particularly interesting insofar as many ratios are not distributed normally (Ooghe \& Van Wymeersch, 1990, p. 392). In addition, it is advised to eliminate the aberrant differences. Effectively, too great a difference could be due to an isolated element, independent of the characteristics of the transmitted companies. The Cochran test makes it possible to eliminate these extreme values. For each indicator selected, differences of the pairs of companies (called Di) were calculated. Then, starting from the Di values, Gi values were calculated corresponding to the report of $\mathrm{Di}^{2}$ of each pair on the sum of $\mathrm{Di}^{2}$ of the whole set of pairs for an indicator. Di values to which $\mathrm{Gi}>0.12$ were then eliminated.
} 
performance indicators we retained result directly from the annual accounts of these companies.

The gross added value (GAV), which is equal to the difference between the sales and the cost of the entries, is the first indicator selected. It is the value which the company added to the cost of the entries by the effective organization of the personnel and the machines. The higher the rate of added value, the more the company transforms its purchases thanks to its personnel and equipment. This GAV is then expressed by person occupied (GAVp) in order to assess workers' productivity.

In order to consider the evolution of the personnel during the succession, two other indicators related to workers are used in this study: the average staff number and average remuneration by worker (Reff).

Also, to allow the data analysis, companies were classified in a time interval ranging between $N$ and $N+3$, where $N$ corresponds to the year of the succession. According to Leker and Salomo (2000), the impact on performance can be observed in the two years following the succession operation. After three years, degradation or an increase in performance would no longer be directly due to the succession operation (technique choice, preparation degree, successor choice, and so on).

\section{Results}

\section{Succession of Family SMEs: Total Social Performance}

Performances of family SMEs who had been subject to a succession were compared with those that had not yet been transmitted. The two following tables ${ }^{7}$ present the observations on the sample as well as the results of the comparison tests ${ }^{8}$ :

Table 1

Matched Samples Test-Transmitted Family SMEs-Performances

\begin{tabular}{|c|c|c|c|c|c|c|c|c|}
\hline & \multicolumn{5}{|c|}{ Differences in pairs } & \multirow{3}{*}{$T$} & \multirow{3}{*}{$d f$} & \multirow{3}{*}{$\begin{array}{l}\text { Sig. } \\
\text { (2-tailed) }\end{array}$} \\
\hline & \multirow{2}{*}{ Mean } & \multirow{2}{*}{ SD } & \multirow{2}{*}{$\begin{array}{l}\text { Mean } \\
\text { Standard } \\
\text { Error }\end{array}$} & \multicolumn{2}{|c|}{ Confidence interval. 95\% } & & & \\
\hline & & & & Lower & Upper & & & \\
\hline GAVp $n+3$ & 7.83855 & 40.95735 & 5.52269 & -3.23378 & 18.91087 & 1.419 & 54 & 0.162 \\
\hline GAVp $n+2$ & 2.01833 & 31.97084 & 4.12742 & -6.24061 & 10.27728 & 0.489 & 59 & 0.627 \\
\hline GAVp $n+1$ & -3.13000 & 32.60281 & 3.86924 & -10.84696 & 4.58696 & -0.809 & 70 & 0.421 \\
\hline GAVp $n-1$ & -1.78529 & 30.55672 & 3.70555 & -9.18160 & 5.61101 & -0.482 & 67 & 0.632 \\
\hline GAVp $n-2$ & -5.00206 & 32.23520 & 3.90909 & -12.80464 & 2.80052 & -10.280 & 67 & 0.205 \\
\hline Average staff number $n+3$ & -0.20000 & 4.95676 & 0.63992 & -1.48047 & 1.08047 & -0.313 & 59 & 0.756 \\
\hline Average staff number $n+2$ & -0.43750 & 5.31806 & 0.66476 & -1.76591 & 0.89091 & -0.658 & 63 & 0.513 \\
\hline Average staff number $n+1$ & -0.40000 & 5.45498 & 0.62989 & -1.65508 & 0.85508 & -0.635 & 74 & 0.527 \\
\hline Average staff number $n-1$ & 0.47143 & 5.61499 & 0.67112 & -0.86742 & 1.81028 & 0.702 & 69 & 0.485 \\
\hline Average staff number $n-2$ & 0.65217 & 5.63556 & 0.67844 & -0.70164 & 2.00598 & 0.961 & 68 & 0.340 \\
\hline Reff $n+3$ & -308.742 & $12,515.291$ & $1,735.5586$ & $-3,793.0213$ & $3,175.5371$ & -0.178 & 51 & 0.860 \\
\hline Reff $n+2$ & $1,681.2607$ & $12,697.505$ & 1,727.9115 & $-1,784.4909$ & $5,147.0124$ & 0.973 & 53 & 0.335 \\
\hline $\operatorname{Reff} n+1$ & -652.6328 & $10,805.416$ & 1,310.3492 & $-3,268.1008$ & $1,962.8352$ & -0.498 & 67 & 0.620 \\
\hline Reff $n-1$ & $1,507.2387$ & $13,378.392$ & $1,685.5189$ & $-1,862.0657$ & $4,876.5430$ & 0.894 & 62 & 0.375 \\
\hline $\operatorname{Reff} n-2$ & 2,533.223 & $13,684.57$ & $1,752.13$ & -971.5603 & $6,038.0062$ & 1.446 & 60 & 0.153 \\
\hline
\end{tabular}

\footnotetext{
7 The first table focuses on the performance indicators; the second, the evolutions between $n-1$ and $n+1, n+2$, and $n+3$, the average before and after succession of the whole set of indicators.

${ }^{8}$ For the presentation of the results, the statistically significant values are highlighted in bold in the tables.
} 
Table 2

Matched Samples Test-Transmitted Family SMEs_Evolution

\begin{tabular}{|c|c|c|c|c|c|c|c|c|}
\hline & \multicolumn{5}{|c|}{ Differences in pairs } & \multirow{3}{*}{\multicolumn{2}{|c|}{$d f$}} & \multirow{3}{*}{$\begin{array}{l}\text { Sig. } \\
\text { (2-tailed) }\end{array}$} \\
\hline & \multirow{2}{*}{ Mean } & \multirow{2}{*}{ SD } & \multirow{2}{*}{$\begin{array}{l}\text { Mean } \\
\text { Standard } \\
\text { Error }\end{array}$} & \multicolumn{2}{|c|}{ Confidence interval. 95\% } & & & \\
\hline & & & & Lower & Upper & & & \\
\hline$\Delta$ GAVp ST & -0.78448 & 30.97893 & 3.78468 & -8.34083 & 6.77188 & -0.207 & 66 & 0.836 \\
\hline$\Delta$ GAVp LT & 13.99063 & 38.58618 & 5.56943 & 2.78637 & 25.19488 & 2.512 & 47 & 0.015 \\
\hline$\Delta$ average GAVp & 8.72790 & 24.90935 & 3.67268 & 1.33073 & 16.12506 & 2.376 & 45 & 0.022 \\
\hline$\Delta$ Average staff number ST & -0.62857 & 2.58856 & 0.30939 & -1.24579 & -0.01135 & -2.032 & 69 & 0.046 \\
\hline$\Delta$ Average staff number LT & -0.86538 & 4.37474 & 0.60667 & -2.08332 & 0.35255 & -1.426 & 51 & 0.160 \\
\hline$\Delta$ mean of Average staff number & -0.78205 & 2.90059 & 0.40224 & -1.58958 & 0.02548 & -1.944 & 51 & 0.057 \\
\hline$\Delta$ Reff ST & $-2,166.552$ & $9,951.508$ & $1,284.734$ & $-4,737.3$ & 404.19527 & -1.686 & 59 & 0.097 \\
\hline$\Delta$ Reff LT & $-3,349.419$ & $14,089.481$ & $2,174.054$ & $-7,740$ & $1,041.17237$ & -1.541 & 41 & 0.131 \\
\hline$\Delta$ average Reff & $-1,991.403$ & $10,297.858$ & $1,608.255$ & $-5,241.8$ & 1,259.00197 & -1.238 & 40 & 0.223 \\
\hline
\end{tabular}

This study gets significant results on the evolution of staff indicators:

- average staff number between $n-1$ and $n+1$ (lower value) and on average before and after succession (lower value);

- average remuneration by worker between $n-1$ and $n+1$ (lower value);

- the gross added value per person between $n+2$ and $n+3$ (higher value) and on average before and after succession (higher value).

Thus, the gross added value per occupied person goes from an average of the negative differences before succession to an average of the positive differences after succession. The succession would thus have a positive influence on the increase in added value per person in the long run. However, for the short term, the results on the sample show that the occupied productivity per person would tend to decrease. Nevertheless, this result is not statistically significant.

On the basis of the sample analysis, average remuneration per worker and average staff number are higher than for family SMEs that were not transmitted in the two years preceding the succession.

With regard to pay, Allouche and Amann (1995) observed that the intermediate technical framing of family SMEs would receive higher average wages in comparison with the wages received by members of non-family SMEs. These two indicators then become lower for the three years following the succession (except average remuneration in $n+2$ ) and are not as low as in not transmitted family SMEs. For example, the average staff number passes from 6.41 units in $n-1$ to 6.07 units in $n+1$ whereas in the case of not transmitted family SMEs, it increases by 5.94 units in $n-1$ with 6.47 units in $n+1$.

It would have been interesting to know the nature of the departures (dismissal, nonrenewal of limited-duration contract, voluntary departure) in order to determine if the changes in personnel were caused by the successor (via dismissals) or if they reflect the will of the employees to leave their company because of uncertainty surrounding the arrival of the new transferee and the projects he intends to develop in the company. Unfortunately, such information is not available. It seems that variable pay is not used to mobilize and motivate the personnel that might nonetheless be reluctant to see a new leader arrive (out of fear of changes in the organization of the SMEs, or fear of a modification in the spirit developed by the former leader). One can 
possibly think that the new leader wishes to devote his capital to the development of new projects for the company rather than to the pecuniary incentive for staff that he has only begun to manage and with which he must above all establish a trusting relationship. This study results contrast with those of Diwisch, Voithofer, and Weiss (2006), who noted a positive effect on employment for SMEs having undergone a succession and a negative effect for similar companies that did not undergo succession. In the same way, the fact that productivity increases following the succession operation goes against the results of Deschamps (1998), who evokes the staff commitment reduction once the company has been transmitted.

These tendencies are confirmed by the analysis of the evolutions (statistically significant results) for a very short time period (for average staff number and average remuneration), for a longer time frame (for the gross added value per person) and for the average before and after succession (for the gross added value per occupied person and average staff number).

The succession of family SMEs thus apparently leads to a compression of remuneration and average staff number in the short run, whereas productivity seems to increase in the long run.

\section{Social Performance of the Succession of Family SMEs According to the Nature of the Successor: Internal or External}

As it was underlined in the review of the literature, a crucial stage during the process of transmitting family SMEs consists of choosing the successor, i.e., the future leader. Is it necessary to choose an internal successor or an external one? In this respect, the studies deliver contradictory results.

To detect a possible difference in performance, two groups of transmitted family SMEs were set up, those with an internal successor and those with an external successor. Social performances of family SMEs that were transferred were then compared with those that had not yet been transferred (always with the aim of highlighting a variation of performance due to succession and not to the economic conjuncture).

Table 3

Matched Samples Test_Family SMEs Transmitted to an Internal Transferee or to an External One-Social Performances

\begin{tabular}{|c|c|c|c|c|c|c|}
\hline \multirow{2}{*}{ Differences calculated on pairs } & \multicolumn{3}{|c|}{ Internal successor } & \multicolumn{3}{|c|}{ External successor } \\
\hline & Average & $T$ & Sig. (2-tailed) & Average & $T$ & Sig. (2-tailed) \\
\hline GAVp $n+3$ & 7.48944 & 1.221 & 0.230 & 10.32353 & 0.0827 & 0.421 \\
\hline GAVp $n+2$ & 5.37610 & 0.954 & 0.346 & -3.90118 & -0.0797 & 0.437 \\
\hline GAVp $n+1$ & -2.11200 & -0.429 & 0.670 & -6.33150 & -1.024 & 0.319 \\
\hline GAVp $n-1$ & 1.36848 & 0.398 & 0.693 & -6.75526 & -0.659 & 0.518 \\
\hline GAVp $n-2$ & -1.25222 & -0.290 & 0.773 & -12.08350 & -1.346 & 0.194 \\
\hline Average staff number $n+3$ & -0.08333 & -0.113 & 0.911 & -0.030000 & -0.212 & 0.834 \\
\hline Average staff number $n+2$ & -0.40000 & -0.486 & 0.630 & -0.50000 & -0.364 & 0.720 \\
\hline Average staff number $n+1$ & -0.50000 & -0.610 & 0.545 & -0.18182 & -0.0166 & 0.869 \\
\hline Average staff number $n-1$ & 0.17021 & 0.187 & 0.852 & 1.45000 & 1.505 & 0.149 \\
\hline Average staff number $n-2$ & 0.19565 & 0.211 & 0.834 & 1.90000 & 2.021 & 0.058 \\
\hline Reff $n+3$ & -201.766 & -0.093 & 0.926 & $-1,105.909$ & -0.340 & 0.738 \\
\hline $\operatorname{Reff} n+2$ & $2,691.244$ & 1.175 & 0.248 & -884.752 & -0.373 & 0.715 \\
\hline Reff $n+1$ & 35.413 & 0.025 & 0.980 & $-2,522.898$ & -0.831 & 0.417 \\
\hline Reff $n-1$ & $2,756.282$ & 1.579 & 0.122 & $-1,128.302$ & -0.265 & 0.794 \\
\hline $\operatorname{Reff} n-2$ & $3,270.034$ & 2.055 & 0.046 & $1,340.009$ & 0.263 & 0.796 \\
\hline
\end{tabular}


Table 4

Matched Samples Test-Family SMEs Transmitted to an Internal Transferee or to an External Transferee-Evolution

\begin{tabular}{|c|c|c|c|c|c|c|}
\hline \multirow{2}{*}{ Differences calculated on pairs } & \multicolumn{3}{|c|}{ Internal successor } & \multicolumn{3}{|c|}{ External successor } \\
\hline & Mean & $T$ & Sig. (2-tailed) & Mean & $T$ & Sig. (2-tailed) \\
\hline$\Delta$ GAVp ST & -2.962 & -0.677 & 0.502 & 2.35368 & 0.294 & 0.772 \\
\hline$\Delta$ GAVp LT & 8.831 & 1.466 & 0.153 & 24.62467 & 1.950 & 0.072 \\
\hline$\Delta$ average GAVp & 6.76097 & 1.559 & 0.130 & 12.60905 & 1.697 & 0.114 \\
\hline$\Delta$ Average staff number ST & -0.68085 & -1.827 & 0.074 & -0.75000 & -1.187 & 0.250 \\
\hline$\Delta$ Average staff number LT & -0.90625 & -1.137 & 0.264 & -1.00000 & -0.905 & 0.379 \\
\hline$\Delta$ mean of Average staff number & -1.01563 & -2.016 & 0.053 & -0.61765 & -0.796 & 0.438 \\
\hline$\Delta$ Reff ST & $-2,839.864$ & -1.807 & 0.078 & $-1,099.730$ & -0.465 & 0.650 \\
\hline$\Delta$ Reff LT & $-4,504.358$ & -1.907 & 0.067 & $-1,837.436$ & -0.367 & 0.720 \\
\hline$\Delta$ average Reff & $-2,847.542$ & -1.619 & 0.117 & -791.608 & -0.210 & 0.838 \\
\hline
\end{tabular}

The conclusions previously reached concerning the total evolution of average staff number in the short run as well as the evolution of short-term remunerations seem to be confirmed for family SMEs that have been transmitted to an internal transferee. The tendencies observed are overall identical within the group of family companies transmitted to an external transferee but the results are not statistically significant.

The pairing tests on the sample of transmitted family SMEs according to whether the successor is internal or external to the company do not make it possible to highlight opposite tendencies. Whatever transferee type, the gross added value per worker is in general higher than that of not transmitted family SMEs. The analysis of the evolution of the indicators confirms these two tendencies even if the results prove only slightly statistically significant with a threshold of $10 \%$. That would thus mean that the occupied productivity per person is higher following the succession of family SMEs, regardless the nature of the transferee.

This conclusion partially joins those of Miller and Le Breton (2005) who stressed the importance of continuity within family companies, which favours the development of a strong core of skills. Thus, one can think that lack of motivation or concern of employees over the departure of their initial leader, and thus worry about the future of their company, would tend to attenuate following the arrival of a successor who could be seen as a guarantor of the continuity of the lines of business and therefore of employment. Miller and Le Breton (2005) also mentioned the principle of community supported the development of an important feeling of membership welded invested of a collective mission. These two principles would seem to still come into play following the succession of family companies, no matter whether the transferee is internal or external.

However, in the short run, the evolution of added value per person is negative after the succession to an internal transferee while this evolution is positive on a longer horizon. This seems to support the conclusions of Sraer and Thesmar's (2007) study highlighting that internal successor such as heirs tend to implement a longer-term company vision.

In addition, the analysis of the results of Table 4, even if they are not statistically significant, highlights a positive short- and long-term development of productivity per occupied worker much more when the company is transmitted to an external transferee. This rise in productivity is partially due to the compression of wages and to the compression of the overall payroll. However, these two types of compression also play a role following the succession of a company to an internal transferee. In addition, the analysis of the results carried 
out on the sample of firm's shows that the compression of wages is much greater when the company is transmitted to an internal person. The results in Table 4 show that the increase of productivity per occupied worker is more important when the company is transmitted to an external successor than to an internal one. Such results meet to some extent the results of previous studies made by Huson, Malatesta, and Parrino (2004), or Morck, Strangeland, and Yeung (1998).

As previously mentioned, results are statistically significant for the evolution of the two other indicators related to the personnel, with regard to succession to an internal successor. However, the tendency observed is the same when the successor is external to the SME. It appears then that the number of workers as well as remuneration tends to decrease for transmitted family SMEs. Even if the variable apprehending the evolution of the average staff number as well as the evolution of remuneration seems statistically significant in the case of with the threshold of $10 \%$. SME transmitted to an internal transferee, the same results are not observed for those transmitted to an external transferee. The results obtained on variable remuneration tend to confirm the existence of a wage decrease when a family SME is transmitted to an internal transferee, as indicated by Sraer and Thesmar (2007). For the group of family SMEs transmitted to an internal transferee, one can think that the staff members accept this wage reduction because of their important commitment to their company (Allouche \& Amann, 1998; Begin, 2006) in the mindset of continuity. In this respect, Ainsworth and Cox (2003) noted that the culture of the family company tended to remain stable when the company was transmitted to future generations.

This wage reduction could also be an explanation for the rise of worker productivity within family companies that are transmitted to an internal transferee. In effect, the reduction in salary costs has the effect of increasing the trading margin the company releases and, consequently, increases the added value per person.

This rise in productivity could be also explained by the personnel confidence and the credibility that it can give to an internal successor (Culliere, 2008) who knows the company and who would be better able to facilitate and justify the community that had developed around the preceding leader, thanks to the relations that were already established with the staff. The personnel would thus more readily agree to sacrifice part of its wages if this decision is made by an internal person who has a good knowledge of the company, rather than by an external person who would modify the HR practices (Saoudi, 2008).

Nevertheless, the results obtained do not make it possible to put forth that human resource management is more protective within in-house transmitted family companies (Sraer \& Thesmar, 2007), given the downward trend amongst workers following the succession of companies. However, data allowing identifying the various sources of wage savings weight (early retirement, dismissals, and so on) were not available.

In addition, the downward trends in remuneration and in average staff number after succession are identical in the two groups of companies. The observations concerning the evolution of the social performance of family SMEs transmitted to an external transferee seem coherent with the results of Sraer and Thesmar (2007) as well as Saoudi (2008). Sraer and Thesmar (2007) went on to show that external successor often had short-term contracts, which obliged them to lay off personnel so as to increase the short-term profitability of the company. Furthermore, according to Saoudi (2008), the external successor often implements a strategy of change in order to settle into their leadership position. This strategy concerns human resource management particularly. In this respect, the compression of personnel after succession could possibly be perceived as one of the means to be implemented by the external transferee to reinforce his role as leader. But here also, data relative to the true nature of the compression of the payroll were not available. 


\section{Conclusions}

This research tried to analyze the impact of a succession operation on the social performance of family SMEs, while determining if the nature of the successor (internal or external to the company) could affect this social performance. This study was interesting to carry out in the sense that the literature seems to have neglected problems focused on the possible relations between the type of transferee and the HR style. The lack of research on this topic also seems to indicate that family SMEs hold little interest for most researchers, despite the fact that they are a driving force in the economy and deserve to be the subject of in-depth study.

It comes out from this research that following the succession operation and in comparison with not transmitted family SMEs, the average staff number of transmitted family SMEs tends to decrease, as well as workers' wages. Moreover, the productivity of transmitted family SMEs seems higher than the productivity of family SMEs that have not been transmitted. It seems that there are no significant differences in these results whether the company is transmitted to an internal transferee or to an external one. According to such results the nature of the successor does not affect social performance of family SME after succession. The observations carried out on this study sample seem to consolidate those made by Sraer and Thesmar (2007), who reported a wage reduction in family SMEs that were transmitted to an internal successor, without this reduction affecting the productivity of the personnel. With regard to the decrease in manpower following succession, this research lacks data that could help to determine the nature of human resources changes or consequently, to determine if the decision to leave the company comes from the employee himself or from the new leader. Interviews with new leaders of studied SMEs could thus constitute an important step in understanding the nature of departures from transmitted family SMEs and would contribute to deepen this analysis.

These interviews could be helpful to better understand human resource strategy adopted by the successor, whether they are internal or external, once succession is over. In addition to the successor perceptions, it would be particularly interesting to take into account staff's perceptions, which must go from a situation of attachment to the initial leader to a possible situation of uncertainty due to the arrival of a transferee whose projects for the company are inevitably unknown and/or not approved. Additional indicators would be necessary to better approach the social performance of transmitted SMEs and to have a better idea of the evolution of their human resource management policy once the succession has been carried out. The evolution of indicators such as training rate, use of part-time or permanent contracts could enable further research to better determine the way in which the new successor intends to manage his staff, which would in turn give researchers a better approach to the social performance of transmitted companies.

\section{References}

Afnor, G. (1988). Statistique: Vocabulaire, estimation et tests statistiques. Paris.

Ainsworth, S., \& Cox, J. W. (2003). Families divided: Culture and control in small family business. Organization Studies, 24(9), 1463-1485.

Allouche, J., \& Amann, B. (1995). Le retour triomphant du capitalisme familial. In De Jacques Cœur à Renault: Gestionnaires et Organisations. Proceedings from $3^{e}$ rencontres Gestionnaires et Organisation. Presses de l'Université des sciences sociales de Toulouse (p. 1-23).

Allouche, J., \& Amann, B. (1998). La confiance: une explication des performances des entreprises familiales. Revue Economie et Société, 8(9), 129-154.

Allouche, J., \& Amann, B. (2000, March). L’entreprise familiale: un état de l'art. Revue Finance-Contrôle—Stratégie, 3(1), 33-69. 
Anderson, R., \& Reeb, D. (2003). Founding family ownership and firm performance: Evidence from the SetP 500. The Journal of Finance, 58(3), 1301-1327.

Arregle, J. L., Durand, R., \& Very, P. (2004). Origines du capital social et avantages concurrentiels des firmes familiales. M@n@gement,7(1),13-36.

Barach, J. A., Ganitsky, J. B., Carson, J. A., \& Doochin, B. A. (1988). Entry of the next generation: Strategic challenge for family business. Journal of Small Business Management, 26(2), 49-56.

Baron, R. A., \& Markman, G. D. (2000). Beyond social capital: How social skills can enhance entrepreneurs success. Academy of Management Executive, 14(1), 106-115.

BDPME. (1998). La succession des PME-PMI: 10 années d'expérience de la BDPME.

Bégin, L. (2006). Motivations et Freins à la reprise de l’entreprise familiale en Suisse Romande. Economie et Société, série K16, 1 , $11-36$.

Boussaguet, S. (2006). Réussir son entrée dans l'entreprise: le processus de socialisation du nouveau dirigeant. Proceedings from 1ères Journées Georges Doriot, Deauville.

Boussaguet, S. (2008). Prise de fonction d'un repreneur de PME: repérages de conditions de facilitation et d'activation. Revue de l'Entrepreneuriat, 7(1), 39-62.

Caby, J. (1994). Motivations et efficacité des offres publiques d’achat et d'échange en France de 1970 à 1990 . Thèse de doctorat, Université de Nancy II.

Cadieux, L. (2006). La succession d'une entreprise familiale: une approche intégrée d'intervention. Revue Organisations et Territoires, 15(3), 15-22

Carlock, R., \& Ward, J. (2001). Strategic planning for the family business. Parallel planning to unify the family and business. New York: Palgrave.

Chabert, R. (2005). Succession d'entreprise, optimiser la prise de relais. Pearson-Village Mondial.

Chabaud, D., Estay, C., \& Louart, P. (2008). Editorial. Revue de l'Entrepreneuriat, 7(1), 1-18.

Chua, J. H., Sharma, P., \& Chrisman, J. J. (1998). Important attributes of successors in family businesses: An exploratory study. Family Business Review, 11(1), 19-34.

Colot, O. (2010). La performance de la Succession des entreprises familiales. Editions Universitaires Européennes.

Cooper, D. R., \& Sschindler, P. S. (2006). Business research methods (9th ed.). Mc Graw-Hill International Edition.

Culliere, O. (2008). Une circonscription de la légitimité du repreneur d'entreprise. Proceedings from $2^{e}$ Journées Georges Doriot. Paris.

Deschamps, B. (1998). La gestion des problèmes humains dans les opérations de reprise de PME par le particulier. Proceedings from 4ème Congrès International en entrepreneuriat et PME. Nancy-Metz.

Deschamps, B. (2002). Proposition d'une typologie des profils de repreneurs d'entreprise. Proceedings from $2^{e}$ congrès de l'Académie de l'Entrepreneuriat (pp.1-13). Bordeaux.

Deschamps, B., \& Cadieux L. (2008). La théorie de la transition de rôle dans la compréhension du processus de la transmission/reprise externe des PME: une ouverture? Proceedings from $6^{\text {ème }}$ journée franco-québécoise de recherche sur le thème de la reprise/succession. IAE de Valenciennes.

Diwisch, S., Voithofer, P., \& Weiss, C. (2006). The Shadow of succession, a non-parametric matching approach. Discussion paper 13.

Flament, F. (2006). La stratégie et la gestion en ressources humaines en PME familiale: recension des écrits. Research note, No. 2006-05, Chaire de recherche du Canada sur les enjeux socio-organisationnels de l'économie du savoir, 1-81.

Heldenbergh, A. (1999). Les motivations et l'efficacité des opérations stratégiques d’OPA sur le marché belge. Thèse de doctorat, Université de Mons-Hainaut (p. 475).

Huson, M., Malatesta, P., \& Parrino, R. (2004). Managerial succession and firm performance. Journal of Financial Economics, 74, 237-275.

Jorissen, A., Laveren, E., Martens, R., \& Reheul, A-M. (2002). Differences beween Family and nonfamily firms: The impact of different research samples with increasing elimination of demographic sample differences. Proceedings from RENT XVI, 16th workshop. Barcelona.

Kenyon-Rouviniez, D., \& Ward, J. L. (2004). Les entreprises familiales. Que sais-je? Paris: PUF.

Kotter, J. P. (1982). The general managers. New York: Free Press.

Leker, J., \& Salomo, S. (2000, September). CEO turnover and corporate performance. Scandinavian Journal of Management, 16(3), 287-303. 
Lin, Z., \& Li, D. (2004). The performance consequences of top management successions. Group and Organization Management, 29(1), 32-66

Meier, O. (2002). Problèmes de succession dans les PME familiales: freins et résistance culturelle. Gestion 2000, juillet-août, 109-126.

Miller, D., \& Le Breton, I. (2005). Managing for the Long Run: Lessons in Competitive Advantage from Great Family Businesses. Boston: Harvard Business School Press.

Morck, R., Strangeland, D., \& Yeung, B. (1998, November). Inherited wealth, corporate control and economic growth: The Canadian disease? NEBR Working paper, 6814.

Morck, R., \& Yeung, B. (2003). Agency problems in large family business groups. Entrepreneurship Theory and Practice, 27(4), 367-382.

Mouline, J. P. (2000). Dynamique de la succession managériale dans la PME familiale non cotée. Revue Finance Contrôle Stratégie, 3(1), 197-222.

Ooghe, H., \& Van Wymeersch, C. (1990). Traité d’analyse financière (4 éd.). PUN.

OSEO BDPME. (2005). La succession des petites et moyennes entreprises, l'expérience d'OSEO BDPME (p. 68).

Parrino, R. (1997). CEO turnover and outside succession a cross-sectional analysis. Journal of Financial Economics, 46(2), 165-197

Perez-Gonzalez, F. (2002). Inherited control and firm performance. Working paper, Columbia University.

Picard, C., \& Thevenard-Puthold, C. (2004). Confiance et défiance dans la reprise d'entreprises artisanales. Proceedings from 7ème Congrès International Francophone en Entrepreneuriat et PME. Montpellier.

Saoudi, L. (2007). Le couple Repreneur/Hommes clés: facteur de succès de la succession? Proceedings from $18^{e}$ congrès de l'AGRH. Fribourg.

Saoudi, L. (2008). Le maintien du Noyau dur et le succès de la succession de PME: mythes ou réalités?. Proceedings from $6^{\text {ème }}$ journée franco-québécoise de recherche sur le thème de la reprise/succession. IAE de Valenciennes.

Sekiou, L., Blondin, L., Fabi, B., Besseyre des Horts, C. H., \& Chevalier, F. (1993). Gestion des ressources humaines. Bruxelles: De Boeck Université.

Senbel, D., \& St-Cyr, L. (2006). La succession d’entreprise: un éclairage sur son financement. Proceedings from 1ères Journées Georges Doriot. Deauville.

Sraer, D., \& Thesmar, D. (2004). Performance and behavior of family firms: Evidence from the french stock market. Working paper, No. 2004-24, INSEE.

Sraer, D., \& Thesmar, D. (2007). Performance and behavior of family firms: Evidence from the french stock market. Journal of the European Economic Association, 5(4), 709-751.

Stavrou, E. T. (1999). Succession in family business: Exploring the effects of demographic factors on offspring intentions to join and take over the business. Journal of Small Business Management, 37(3), 43-61.

Thietart, R. A. (1999). Méthodes de recherche en management. Paris: Dunod.

Wtterwulghe, R., Janssen, F., Mertens, S., \& Olivier, F. (1994). Le financement de croissance des entreprises moyennes belges par le recours au capital à risque. Louvain-La-Neuve, IAG. 